\title{
Inefficient presentation of tumor-derived antigen by tumor-infiltrating dendritic cells
}

Patrizia Stoitzner · Laura K. Green · Jae Y. Jung •

Kylie M. Price · Haley T. Ataera · Bronwyn Kivell •

Franca Ronchese

Published online: 5 June 2008

(C) Springer-Verlag 2008

\section{Erratum to: Cancer Immunol Immunother}

\section{DOI 10.1007/s00262-008-0487-4}

Please note that the name of one of the authors of this article is spelt incorrectly, and should read Haley T. Ataera.

The online version of the original article can be found under doi:10.1007/s00262-008-0487-4.

P. Stoitzner · L. K. Green · J. Y. Jung · K. M. Price ·

H. T. Ataera $\cdot$ F. Ronchese

Malaghan Institute of Medical Research,

Wellington, New Zealand

P. Stoitzner $(\square)$

Department of Dermatology and Venereology,

Innsbruck Medical University, Anichstrasse 35,

6020 Innsbruck, Austria

e-mail: patrizia.stoitzner@i-med.ac.at

B. Kivell

Victoria University, Wellington, New Zealand 